\title{
OPTIMIZATION OF ACHIEVEMENTS ASSESSMENT OF PRESCHOOL CHILDREN
}

\author{
Sada Ramanauskienè \\ Klaipeda University, Lithuania \\ Aida Norviliene \\ Klaipeda University, Lithuania
}

\begin{abstract}
In this article the authors present the system assessing the achievements of preschool children in Lithuania, the teacher's opinion regarding the description of achievements assessment of preschool children and its adaptation in a preschool education institution. This article presents the recommendations for the optimization of achievements assessment of preschool children. The quantitative research was applied in accordance with the interpretative attitude, a total of 130 preschool education teachers and managers from Klaipeda region. The results: optimization of implementation of description, assessing the achievements of preschool children, by preparing the model of description; motivation of teachers to improve the skills of assessing the achievements of children, rationalizing and allocating the cost of labor in the teaching process; better education planning process with regard to children's individual needs and abilities, which are determined in the model of achievements assessment of preschool children.
\end{abstract}

Keywords: preschool children, assessment of achievements, optimization of assessment.

\section{Introduction}

Preschool education focuses on the education of a child. According to the United Nations Convention on the Rights of the Child (1989), each child is recognized as a unique, changing and active personality. The Lithuania's Progress Strategy "Lithuania 2030" focuses on public education and training. The strategy notes that creativity and leadership must be assessed and fostered from an early age, also, that there is a need to build and implement learning programmes, which are open to creativity, exploration and development in all educational institutions, and the system of assessment and self-assessment of one's competence. In The National Education Strategy 2013 - 2022, regarding the achievements of Lithuania in the field of access to education, it is emphasized that there is a need to develop alternatives of education system that would be affordable, attractive and valuable to social groups that are now poorly included into education - preschool children, social risk group adolescents, 
adults, as well as rural population (The National Education Strategy 2013 2022; 2013).

The pursuit of preschool education - to help a child to develop the basics of self-sufficiency, healthy lifestyle, positive interaction with adults and children, creativity, knowledge in their environment and country, the ability to learn, referring to child's natural abilities, his individual experience, in accordance with the evolution regularities. As a result, The Description of the Achievements of Preschool Age Children (2014) was framed, which enabled to assess child's achievements more accurately. The education and learning process is based on the values of social justice, equivalence and tolerance. A presumption, that a child is educated and educates during his stay in preschool or day group, is pursued.

Problematics and overview of previous researches. Lately, the issue of quality of educational services, regarding preschool education, is particularly being analyzed and discussed. This was inspired by a number of circumstances related to the change elements in child's social role, representation of the interests of education service users (pupils' parents), the transfer and application of general principles of quality in the sector the of preschool age children's education.

Many Lithuanian and foreign scientists: Glebuvienè et al., 2006; Brassard \& Boehm, 2007; Juodaitytè, Gaučaitè, \& Kazlauskienè, 2008; Neifachas, 2008; Songailienè, 2008; Boyd \& Bee, 2011; Brenneman, 2011; Alasuutari \& Markstrom, 2011; Bernotienè et. al., 2012; Žukauskiene, 2012; Diamond et al., 2013; Bath, 2012; Gerd et al. 2013; Indrašienè \& Žibènienè 2014; Rintacorpi, Lipponen, \& Reunamo, 2014; Knauf, 2015; Bernotienè et al., 2015; Gaižauskaitè \& Valavičienè, 2016; et al., researched the assessment, documentation and information of child's achievements. However, only few researches that reveal teachers' attitude towards the evaluation and documentation of child's progress and achievements are accomplished. The assessment is very important in order to improve the educational process, since the quality of education is also assessed regarding children's achievements. The data of continuing studies (by The Organization of Economic Cooperation and Development - OECD, 2008) reveal that qualitative preschool education helps to solve many social problems - poverty, unemployment, reduces addictions, improve academic performance and has a positive impact on the well-being (The Quality of Early Childhood Education, 2012).

The aim - the optimization of implementation of "The Description" while assessing the achievements of preschool aged children.

The methods of analysis: analysis of literature and documents, questionnaire, quantitative and qualitative methods of data analysis, interpretation. 


\section{The Concept of Assessment of Preschool Children}

Bernotienè, Juraitienè and Jakavonytė-Staškuvienè (2012) point out the aims, which, according to the authors, are assessed in order to: know the child (his educational needs, interests, hobbies, power, style and peculiarities of character, cultural differences); reveal child's efforts and progress and promote his development; contemplate (reflect) the achievements of programme's goals and objectives; plan further education prospects individually for each child and a group of children; adjust education plans, after summarizing the available assessment information; provide a child, his parents and other educators with assessment information.

According to Indrašienè and Žibėnienè (2014) the assessment should reflect what a person seeks to learn, who has learned something, in which ways the educational process takes place, whether it takes place without ignoring the individual pupil's learning pace and methods, referring to pupil's needs, whether the assessment changes pupil's learning, promotes learning motivation, guiding him to lifelong learning. It depends on the evaluation objectives which assessment type to choose.

Three types of assessment are distinguished: diagnostic, formative and summative. Diagnostic and formative assessments are used in the education process of children, in order to obtain feedback on the achievements and progress of children and the quality of the educational process. Summative assessment is used after finishing a part of the program or an entire program (pre-school methodical recommendations: How to monitor and assess children's learning achievements and progress, 2015).

While planning the assessment of child's educational achievements, the following aspects are provided:

- attributes/criteria for evaluating child's progress (individualized educational areas of children's learning achievements symptoms, such as cognitive skills token willingly explores the environment);

- periods (monthly, quarterly, half-year or so on.). The assessment of achievements of preschool children is recommended to be carried out twice a year - at the beginning of the school year and at the end. Intermediate assessments are carried out only in cases when large gaps in education are revealed.

- participants (child, teachers, parents and other educators), their awareness of child's performance techniques. The evaluation results are discussed in private conversations with parents, institution's administration and preschool teachers during the methodical group meetings; 
- methods (observation, conversation, audio, video, blogs, teacher's notes, self-assessment of children's educational achievements, etc.).

- recording and documentation (portfolio, achievements description, observation protocols, video, audio material, etc.). Information about a child, his achievements and progress made is gathered in "Child's folder", in which child's observation protocols, creative work examples that reflect the achievements, child's sayings about himself, the surrounding people, the life in a group, family, teachers' observations, parents' thoughts about a child, friends' assessments are collected and stored;

- other options (assessment options/particularities of alternative education systems) (Bernotienè, Juraitienè, \& JakavonytèStaškuvienė, 2012; Rintakorpi, Lipponen, \& Reunamo, 2014).

While observing children a teacher can choose acceptable and appropriate educational techniques and methods which help to get captured the data of preschool children's achievements and progress, the results of their activities, analysis of their works. It is necessary to involve parents in the educational activities in order to pursue the successful results regarding the achievements of children.

\section{A Short Description of the Achievements of Preschool Aged Children}

In 2014, while implementing The EU Structural Funds Project, The Description of the Achievements of Preschool Age Children (hereinafter - The Description) was framed. "The Description" - a guidance to preschool class teachers and other educators, which provides the whole of acquired moral values and basic skills, also the achievement steps, describing the progress of a child from birth to six years of age.

According to the group leader of promoters of "The Description" Monkevičienè (2015) states that "The Description" is not a standard, this is a guidance document, which aims to help to improve the quality of education. It is based on the attitude that all children are different, and each educates at a different pace. "The Description" is regarded as a document, identifying the direction of children's educational progress. It helps teachers to understand better how the capacities of a child develop, and to organize education (learning) more appropriately, so that child and the teacher's efforts would be directed towards the development of these abilities.

While implementing "The Description ", an assumption that each child's progress depends on his individual strengths and professionalism of educators, is being followed. The purpose of "The Description" - to help preschool class 
teachers and other educators to identify children's learning achievements and needs, to develop preschool education programme purposefully, to implement the curriculum, by adapting it to each child and a group of children, to observe children's progress and educate each child purposefully.

"The Description" indicates its purpose, provisions on its formation, guidance on the improvement of preschool education and the educational process, the educational achievements and their steps of preschool aged children are presented, also, the signs, which encourage a teacher to draw attention towards child who experiences difficulties, are introduced. The main part of "The Description" is the educational achievements of preschool aged children, referring to the stages that reveal the progress of a child from birth to six years of age. Achievements are divided into 18 areas, each of which is described in 7 steps, which relatively refer to the educational year regarding child's age. The following development areas are provided: 1. The daily living skills, 2. Physical activity, 3. Emotion perception and expression, 4. Self-regulation and selfcontrol, 5. Self-perception and self-esteem, 6. Relationship with adults,7. Relationship with peers, 8. Oral language, 9. Written language, 10. Environmental cognition, 11. Calculation and measurement, 12. Artistic expression, 13. Aesthetic perception, 14. Initiative and perseverance, 15. Exploration, 16. Troubleshooting, 17. Creativity 18. Ability to learn. The abilities, which are assigned to each step from 1st to 7th, are described.

\section{The research methodology and results}

The research aimed to optimize the implementation of the preschool age children achievements by preparing the model of "The Description" application; to encourage teachers to improve the skills of assessing the achievements of children by rationalizing and allocating working time in the teaching process; to plan the educational process better, referring to children's individual needs and abilities, which are determined using research-based model of assessing the achievements of children.

A questionnaire method in writing was selected for the research. The questionnaire method was used because of its versatility and optimal use of time to achieve the foreseen research results (Cohen, Manion, \& Morrison 2011; Kardelis, 2016). By means of this method the attitudes of respondents towards assessing the achievements of preschool children were studied. The quantitative research in accordance with the interpretative provisions was used, 130 teachers and principals from 12 preschool institutions of Klaipeda region were interviewed. The survey was conducted from October to December, 2016; the questionnaire consisted of three sets of questions: demographic, problematical and forward looking questions. The semi-opened and open questions were used. 
The aim was to ensure the principles of anonymity and confidentiality, free will and justice, the highest ethical standards in research were being followed.

After the analysis of scientific literature and articles, it was obvious that there was no particular template or model how to mark the achievements of a child. While analyzing, a number of different schemes or tables, which can be marked with the child's achievements, were also found, but the research sought to find out what scheme or pattern is used by the respondents. The data revealed that all the respondents more or less follow The Description in their work.

Table 1 The system of children's achievements assessment, used by teachers

\begin{tabular}{|l|l|}
\hline Follow the scheme composed in accordance with The Description & $51 \%$ \\
\hline Follow their own pattern in accordance with The Description & $40 \%$ \\
\hline Use the table, provided in The Description & $9 \%$ \\
\hline
\end{tabular}

The majority of teachers $(51 \%)$ indicate that they use "The general step assessment system, created in their educational institution". Usually, preschool educational institutions create a unique system for assessing children's abilities and all the teachers follow it in their work. This is quite convenient for the administration of educational institutions, however, in this case teachers work uncreatively, according to the same scheme. $40 \%$ indicates that they follow „their own assessment pattern, based on the steps, presented in The Description". And only $9 \%$ of teachers use the tables, provided in The Description of the Achievements of Preschool Age Children.

During the research it was pursued to ascertain the common attitude of teachers towards "The Description". The options of responses to this question were divided by means of ordinal scale. The majority of respondents provided positive answers, as "very good" and "good" were marked by $77 \%$ of the respondents (cf. 40 and 37). Indifferently, a response "Neither bad nor good", was chosen by $17 \%$ of respondents and $6 \%$ of the surveyed teachers evaluated "The Description" as "bad". It can be stated that "The Description" is valued positively by the majority of preschool teachers, however, nearly one-fifth of the teachers are not in a hurry to assess or evaluate the Description unfavorably.

It was pursued to find out what methods and techniques are used by teachers while assessing children's achievements. Observation is always applied by the majority, i.e. $(92 \%)$, of the respondents. $87 \%$ of respondents note that they always apply: a conversation with a child, a conversation with parents and professionals $(85 \%)$. Teachers often apply the photos of children $(82 \%)$, the tasks, performed by children (51\%), children's stories (49\% of respondents). Many, i.e. $90 \%$, respondents note that they rarely use video, audio materials of children's activities, $57 \%$ rarely uses plus-minus system. 


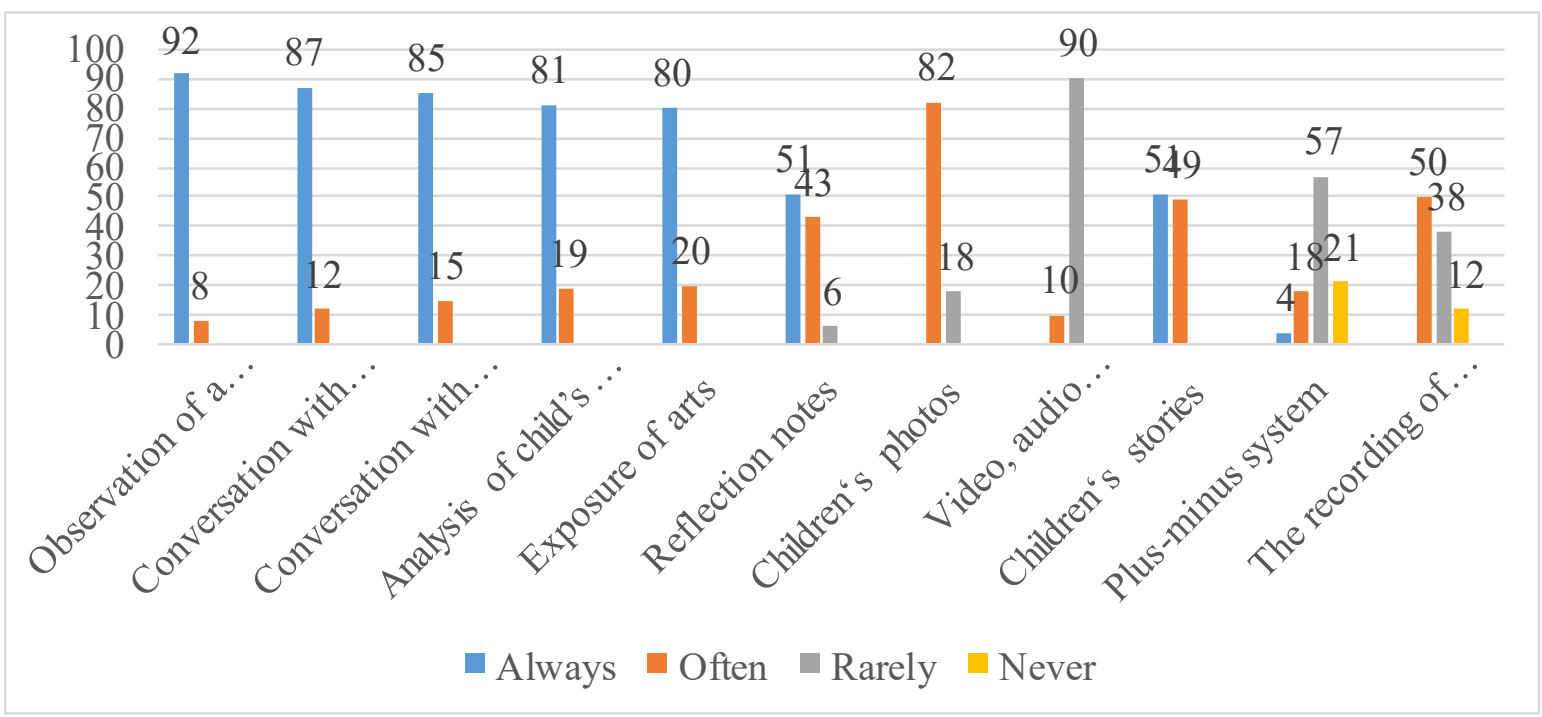

Figure 1 Methods and ways while assessing children's achievements

By means of open questions, it was pursued to know the manner, in which teachers observe and record children's achievements. The respondents indicated that they observe children daily: "In the activities of daily living", "Everyday", "Every day during the activities and games", "During activities of daily time", "During activities". The answers were received, that certain situations are being created. In addition, it was said that they take notes of their observations in writing, on a piece of paper", "Tables are filled in by hand/in writing", "Observations are noted every day". Computers are also used: "While assessing, The Description on the computer is read", "Two ratings charts are created on the computer".

During their work, teachers constantly observe children, record their activities and create certain situations in order to assess child's abilities more thoroughly. Observation of children takes place all year round, however, the achievements themselves are also summarized in achievements lists, child's folders or other documents and are recorded usually 2-3 times per school year. The majority of respondents, i.e. $86 \%$, carry it out 2 times a year, $14 \%$ captures 3 times a year, other options were not pointed out by the respondents.

Teachers usually record the data of children's observation by marking the achievements steps in tables or graphs, carry out children's observation every day and they have to mark a variety of observations regarding children's progress. The informants use computers only while reading The Description, or creating a variety of charts, which aim to compare the results and to record the progress or lack of it in certain areas of education.

By means of open questions it was pursued to find out what has changed in teachers' work since the Description began to be used. The received responses 
can be divided into 3 parts. $57 \%$ of respondents state that the introduction of The Description has made the work more convenient, "I can perceive children's difficulties more easily", "It is more clear and easier to notice children's achievements", "More easier". The majority of respondents, i.e. $52 \%$, state that it is better to organize the individualization of child's education: "I notice who needs more help", "Much easier to analyze a child individually", "Can plan individual education plans more accurately", "Each competence is analyzed in more detail", "It has been observed that insufficient attention is paid towards each child individually". Also, the noticing of strong - weak areas of children has become easier for $38 \%$ of teachers: "The strong and weak areas of children's abilities can be seen", "Has helped to notice the backwardness of some children in certain areas". It can be seen that the majority of teachers observe the positive side of "The Description ", are aware that pedagogical work has become more convenient, the achievements of children and their assessment are more clearly defined, an opportunity to better assess the abilities of each child and all educational group, in general, is provided.

The aim was to find out, in which ways "The Description" makes teacher's life easier and in which - more difficult. The majority, i.e. $72 \%$ of respondents consider their work to be easier, since the following "The Description", the assessment of children's achievements is carried out more precisely: "It is easier to plan the curriculum", "Every step is described in "The Description", "The Description" and methodological recommendations provide exact information on what a child should be able to do", "I assess children"s capacity regarding his competencies more accurately". It is also more convenient to look deeper into each child's abilities: "Each child gets more precise individual insight". According to the respondents, it is important that the areas and steps of "The Description" are related to the competence. "There is exact information on what a child should be able to do", "I assess the abilities of children, regarding their competences, more accurately". In this way the continuity between preschool education and preprimary education is being carried out. Even $87 \%$ of the respondents replied to the question, regarding difficulties while applying "The Description", that its usage in pedagogical work takes a lot of time: "It takes a lot of time", "There are a lot of areas and steps, the assessment takes a lot of time", "Time-consuming", "It takes a long time". $63 \%$ of the respondents state that in order to use "The Description", it must be analyzed very carefully: "There is much to read, to go deeper", "It takes a lot to read and analyze "The Description", "It is hard to understand, which step to mark for a child". $30 \%$ states that the process of assessment should include children's parents. "Soon, the parents will be included in the assessment", therefore, it is likely that the teacher, who performs the assessment of children's achievements, will have much work, since the children will be also evaluated by their parents. The 
results show that the pedagogical work has become more precise, educators can better pay attention towards each child's individuality, but all agree on the fact that the usage of "The Description" takes a lot of time and effort. It is likely that after a few years, teachers will remember the steps of each area by heart and it will be easy to choose the achievement, suitable for a child, however, assessment of achievements will require much of teachers' working time until they have not learned the description of each step.

The aim was to get suggestions from teachers on how to optimize the assessment methodology. It was found out that, according to the teachers, The Description has too many areas: "I would adjust the areas, they should be less and more specific", "A lot of areas", "Without a book there is no work, the essence of some areas and steps are repeated", "The essence of areas are repeated", "Similar descriptions of some steps". The respondents complained that the size of "The Description" is inconvenient: "Long description". All the respondents indicated that the contents of fields and steps in "The Description" are too huge, it is also noted that the areas or steps are very similar, therefore, according to the teachers, they are repeated and it is inappropriate to analyze very similar areas, because it takes a lot of time and effort.

Taking into the account the results of the research, it was expected to create a model that would fit the observations and steps to be noted down, however, while recording children's behavior, this template appeared to be inappropriate, it had to be adjusted until it was the most comfortable to be used. It was planned to note down each step achieved by a child in separate tables, by adding a comment or a picture next to it. During the course of the research it was noticed that separate tables for the all 18 areas take up too much space and are uncomfortable to be filled in. It was decided to create a combined table, which would list all 18 areas and include a space for recording the steps and comments. It includes all the information from the three observations, carried out during a year, while the bottom of it contains a necessary space for a summative comment. The model, assessing the achievements of preschool aged children, is shown in Figure 2.

While preparing the model for assessing the achievements, it has been observed that it would be more convenient for teachers to use an electronic version, which would create new opportunities not only for comments, summaries, records of each child's progress to be noted down, but also to preserve the material, illustrating the achievements: the videos of evaluation process, photos of children's art works, etc. It would become convenient to introduce the parents with the achievements and better involve them in the education and assessment process. 


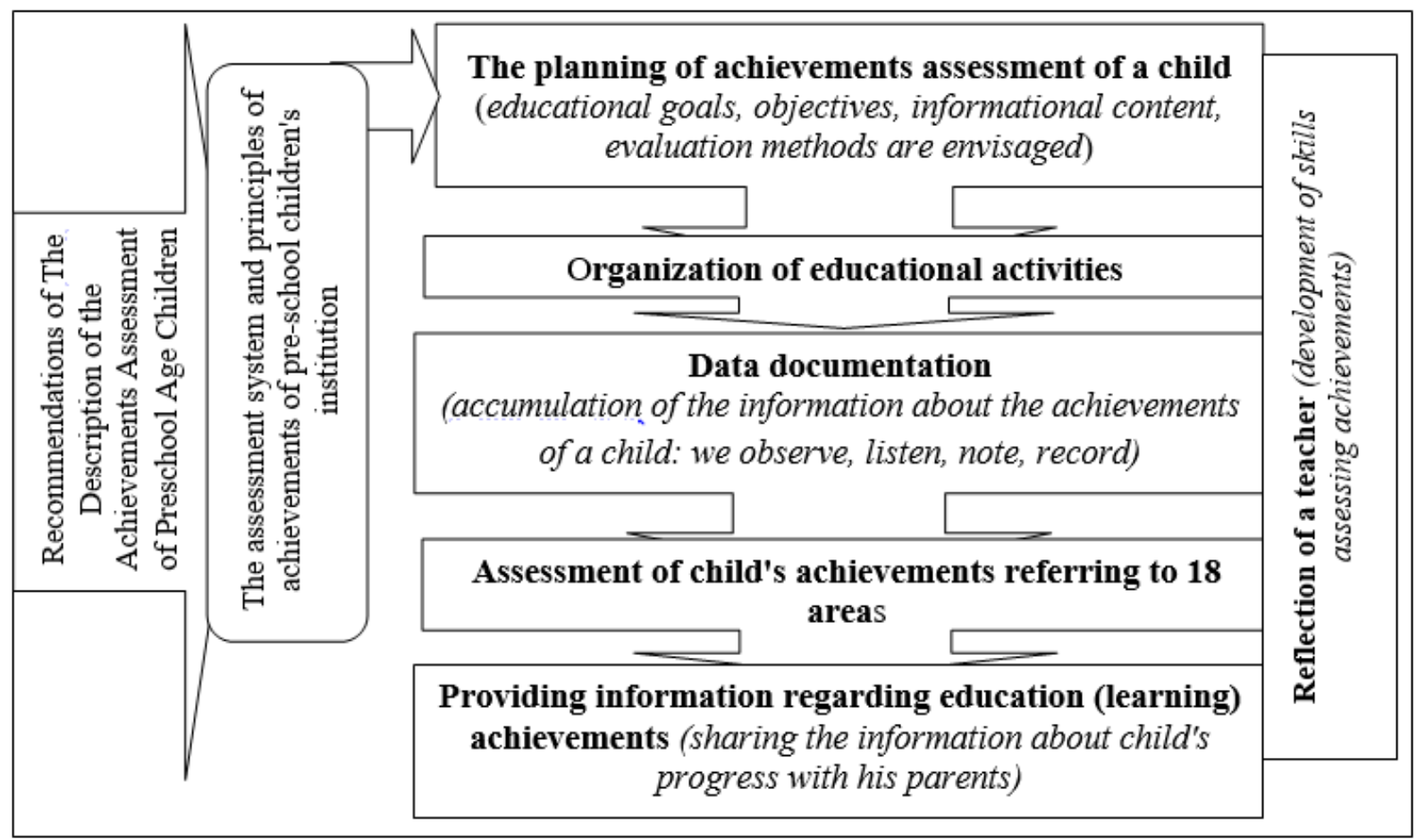

Figure 2 The model, assessing the achievements of preschool aged children

Thus, while pursuing to achieve the provided results of the current research, the course of it was adjusted - in the perspective it was intended to cooperate with IT specialists, who would create and / or adapt an electronic version of the model of preschool children's achievements assessment.

\section{Conclusions}

Lithuanian strategic documents focus on improvement of the quality of education, they stress a need to develop alternatives of the education system. The pursuit of preschool education - to help a child to develop the basics of selfsufficiency, healthy lifestyle, positive interaction with adults and children, creativity, knowledge in their environment and country, the ability to learn, referring to child's natural abilities, his individual experience, in accordance with the evolution regularities. Referring to this provision, The Description of the Achievements of Preschool Age Children (2014) was framed, which enabled to assess child's achievements more accurately. After starting to use The Description, it became clear that there is a need to develop a model, assessing and documenting child's achievements, which would be convenient to use in practice. 
Empirical research revealed that teachers mainly use the schemes either created by institutions or developed by themselves, referring to "The Description" and documentation of child's achievements assessment. It was found out, which methods and techniques teachers use while assessing children's achievements, how and how many times this is done. During the research it was found out what, according to the teachers, changed in their work after "The Description" had been introduced and how the evaluation and documentation system should be optimized. On the basis of this research the model of assessment and documentation of preschool aged children's achievements was framed. The implementation of this model will help to optimize the assessment of preschool children's achievements.

\section{References}

Alasuutari, M., \& Markstrom, A-M. (2011). The making of the ordinary child in preschool. Downloaded from EBSCO <http://web.a.ebscohost.com/ehost/pdfviewer/ pdfviewer?sid=254f8f1f-58c1-4c66-a3a5-c9627dec74e5\%40sessionmgr4004\&vid= $16 \&$ hid $=4212>$.

Bath, C. (2012). 'I can't read it; I don't know': young children's participation in the pedagogical documentation of English early childhood education and care settings. Downloaded from Tailor \& Francis Online < http://ezproxy.biblioteka.ku.lt: 2082/doi/full/10.1080/09669760. 2012.715242>.

Bernotienè, R., Jankauskienė, L., Jonynienè, V. et.al. (2015). Jūsu vaikas ikimokyklinukas. Lietuvos Respublikos švietimo ir mokslo ministerija.

Bernotienè, R., Juraitienè, I., \& Jakavonytė-Staškuvienė (2012). Ikimokyklinio amžiaus vaiku ugdymo pasiekimu vertinimas. Metodinès rekomendacijos. Vilnius: Ugdymo plètotès centras.

Boyd, D., \& Bee, H. (2011). Augantis vaikas. Vilnius: Standartų spaustuvè.

Brassard, R. M., \& Boehm, E. A. (2007). Preschool assessment: Principles and practices. Downloaded from <https://books.google.lt/books?hl=en\&lr=\&id=_njybziE51YC\&oi= fnd\&pg $=$ PR1\&dq= preschool+assessment + framework\&ots $=\mathrm{aP} 2 \mathrm{H} 8 \mathrm{aN} 5 \mathrm{GI} \& \mathrm{sig}=\mathrm{jD} 8 \mathrm{yOs}$ 582vntfCTMY0yOG0995VA\&redir_esc $=\mathrm{y} \# \mathrm{v}=$ onepage $\& \mathrm{q}=$ preschool $\% 20$ assessment $\%$ 20 framework $\& \mathrm{f}=$ false $>$.

Brenneman, K. (2011). Assessment for preschool science learning and learning environments. Downloaded from EBSCO: <http://www.eric.ed.gov/contentdelivery/servlet/ERIC Servlet?accno=EJ931225>.

Convention on the Rights of the Child (1989). Downloaded from $<$ https://www.unicef.org/crc/>.

Cohen, L., Manion, L., \& Morrison, K. (2011). Research methods in education. London: Routledge.

Diamond, K. E., Justice, L. M., Siegler, R. L., \& Snyder, P. A. (2013). Synthesis of IES research on early intervention and early childhood education. Downloaded from EBSCO $<$ http://eric.ed.gov/?id=ED544212 $>$.

Gerde, H. K., Schachter, R. E., \& Wasik, B. A. (2013). Using the scientfic method to guide learning: an integrated approach to early childhod curriculum Downloaded from 
EBSCO: $\quad<$ http://web.a.ebscohost.com/ehost/pdfviewer/pdfviewer?sid=254f8flf-58c14c66-a3a5-c9627dec74e5\%40sessionmgr4004\&vid=10\&hid=4212>.

Ikimokyklinio amžiaus vaiku pasiekimy vertinimo aprašas. (2014). ŠMM. Klaipèda: UAB „Baltic Printing House“.

Ikimokyklinio ugdymo metodinès rekomendacijos. (2015). ŠMM. Klaipėda: UAB „Baltic Printing House“.

Ikimokyklinio ugdymo kokybe. (2012). Downloaded from http://www.nmva.smm.lt/wpcontent/uploads/2012/12/Ikimokyklinio-ugdymo-kokybe-2012-rugs\%C4\%97jis.pdf

Indrašienè, V., \& Žibėnienė, G. (2014). Pasiekimu vertinimas ir isivertinimas. Vilnius: Mykolo Romerio universitetas.

Kardelis, K. (2016). Moksliniu tyrimu metodologija ir metodai. Vilnius: Mokslo ir enciklopedijų leidybos centras.

Knauf, H. (2015). Styles of documentation in German early childhood education. Downloaded from Tailor \& Francis Online <http:/ezproxy.biblioteka.ku.lt:2082/ doi/full/10.1080/09575146. 2015.1011066>.

Lietuvos pažangos strategija „Lietuva 2030“. (2012). Downloaded from $<$ https://eseimas.lrs.lt/portal/legalAct/lt/TAD/TAIS.425517>.

Monkevičienè, O. (2015). Kas naujo ikimokyklinio amžiaus vaikų pasiekimų ir pažangos vertinimo srityje? Švietimo naujienos. Informacinis leidinys. Nr. 2. Vilnius: ŠMM Švietimo aprūpinimo centras.

Rintakorpi, K., Lipponen, L., \& Reunamo, J. (2014). Documenting with parents and toddlers: a Finnish case study. Downloaded from Tailor \& Francis Online < http://ezproxy.biblioteka.ku.lt:2082/doi/pdf/10.1080/09575146.2014.903233?needAcces $\mathrm{s}=$ true $>$.

Valstybine švietimo 2013 - 2022 metu strategija (2013). Downloaded from: $<$ https://www.smm.1t/uploads/lawacts/docs/451_f91e8f0a036e87d0634760f97ba07225. pdf $>$.

Žukauskienè, R. (2012). Raidos psichologija: integruotas požiūris. Vilnius: Margi raštai. 